\title{
TECHNICAL TEACHERS' SELF-EFFICACY AND QUALIFICATIONS AS CORRELATE ON STUDENTS' ACADEMIC PERFORMANCE IN BASIC TECHNOLOGY
}

\author{
Jane Itohan Oviawe ${ }^{1, ~}{ }^{*}$ and David Omoh ${ }^{2}$ \\ ${ }^{1}$ Department of Vocational and Technical Education, Ambrose Alli University, KM 70 Benin Auchi Road \\ P. M. B 14, Ekpoma, Edo State, Nigeria \\ ${ }^{2}$ Department of Geoscience, University of Lagos, Akoka-Yaba, Lagos, Nigeria \\ E-mail: janeoviawe98@gmail.com; janeoviawe@aauekpoma.edu.ng* \\ *Corresponding Author
}

\begin{abstract}
Teacher qualification is one of the predictors of their self-efficacy which contributes positively to the students' learning outcomes. Technical teachers' lack of confidence in Basic Technology classes has become a worsening element linked to their lack of certification and shallow knowledge, which has an unfavorable influence on students' learning outcomes. Using a correlational research methodology, this study assessed the technical instructors' self-efficacy and credentials as correlates of students' academic achievement in Basic Technology in Edo State. The population for the study was made up of 448 technical teachers. A multi-stage sampling method was adopted in the selection of schools for this study. Six local governments were selected as clusters and the schools were selected using a simple random sampling technique within the clusters. A purposive random sampling technique was used to sample 126 technical teachers involved in this study. The instruments used for data collection were Teacher Self-Efficacy Scale (TSES) with a Cronbach Alpha reliability of .76 and students' JSS III mock examination scores for their achievement. The data obtained were analyzed using Pearson Product Moment Correlation coefficient and regression analysis. The findings indicated that $40 \%$ of the difference in students' academic performance in Basic Technology was due to technical teachers' qualifications and that there was a strong link between technical teachers' self-efficacy and students' academic success in Basic Technology. The study's findings suggested, among other things, that technical teachers' selfefficacy should be taken into account when it comes to students' academic achievement in Basic Technology.
\end{abstract}

Keywords: academic performance, basic technology, self-efficacy, technical teachers' qualification

\section{INTRODUCTION}

Education is the foundation of any country's progress. The total growth of a country is dependent on educational progress, in which the teacher is a key role and component. To this end, Uwameiye \& Oviawe and Ejima \& Okutachi [1], [2] asserted that for the alternative of national objectives, the quality and quantity of teachers matters, hence the need for teacher self-efficacy. Teachers who are properly prepared and trained, according to Owolabi [3] and Oviawe [4], are more successful in the classroom and have the biggest impact on students' learning in school topics such as Basic Technology.

The junior secondary school level of education is referred to as the upper basic education level. It is the first three years of secondary education that expose students to acquire knowledge and prevocational skills through exploration. The prevocational curriculum incorporates basic skills for entrepreneurship and life-long learning. Prevocational subjects include agricultural science, Basic Technology, business studies, home economics, among others.

Basic Technology is the only core prevocational subject that exposes its recipients to the fundamental principles of technology. It helps to unify technology for students' better understanding. It is aimed at developing students' interest in technology and creating awareness in designing and exploring the various technical careers. Metalwork, woodwork, applied electrical, basic electronics, technical drawing, car, airflow, water flow, physics, chemistry, food preservation, ceramics, 
plastics, and building give a vast range of expertise for a link [5]. According to Uwameiye \& Oviawe [1], students get a deeper grasp of industrial and business processes as a result of their exposure to this topic, as well as the ability to expose their particular interests and aptitudes. Students can also acquire positive qualities and attitudes, such as pride in productive work, authority respect, and labor dignity. These are qualities that can pique a person's interest in technology and empower them to be selfsufficient. According to the Federal Ministry of Education [6], Basic Technology objectives include: (1) instilling technological literacy, or a basic understanding of and capability in technology; (2) exposing students to the world of work to match their talents and interests for wise vocational choice; and (3) instilling positive attitudes toward work as a source of human identity. These admirable goals will not be realized without capable instructors.

What a teacher knows is of critical importance because it influences what the students will learn. Teachers' competency plays a primary role in the overall success of a nation. Teachers' knowledge is essential in the adequate preparation of students' progress in society, to achieve set objectives [7]. The quality of all educational sectors has been directly impacted by teacher quality in terms of credentials, experience, competency, and degree of devotion to work [8]. Thus, the success of the instructional process that influences students' learning outcomes depends on teachers' effectiveness, efficacy, and qualification.

In this context, qualified teachers are teachers who have undergone professional training in addition to having a firm grasp of Basic Technology as a subject. Teachers' lack of basic knowledge and skills required for appropriate technical teaching implies poor technical education and non-attainment of national goals and objectives as well as lack of implementation of curriculum that has cost the nation a lot of money [9]. Nigeria places importance on the quality of teachers' prerequisite qualifications, therefore, it needs priority attention. Teachers must have the right qualifications and experience, according to Udofot [10], to influence learners' skills for productive and engaging practical tasks. The National Certificate of Education (NCE), the Post-Graduate Certificate in Education (PGCE), the Professional or Post Graduate Diploma in Education (PGDE), the Bachelor of Science in Education (B.Sc. (Ed)), and the Master of Science in Education (M.Sc. (Ed) are all examples of teaching qualifications in Nigeria (Ed), and Doctor of Philosophy in Education (Ph.D. (Ed)). These teacher certifications are given mostly by higher educational institutions.

In Nigeria, this teacher qualification is a professional degree that allows a person to become a registered teacher with the Teachers Registration Council of Nigeria (TRCN). It also authorizes a teacher to teach and grade in schools. Unfortunately, some technical teachers in secondary schools did not undergo professional training to enable them to get skills, qualities, and enough knowledge of the subject matter and how to impart the knowledge to the learners. Teachers, according to Aguba [11] are the most important influencers of educational quality. Azar [8] went on to say that instructors' quality is completely determined by their self-efficacy as a measure of their ability to change their personality traits. Self-efficacy, according to Mary et al. [12] is an essential motivational component that determines the effectiveness in enhancing students' success in any classroom.

Teaching is a hard profession that necessitates defined teacher self-efficacy, indepth topic, material, age, and pedagogical knowledge, as well as a wide range of qualities such as patience, leadership, and creativity [13]; flexibility, resourcefulness, imagination, critical thinking, and honesty. In addition to these, the technical teacher should develop a positive attitude as well as the required skills in teaching Basic Technology. According to the CFNC, to achieve the objective of education, the teaching profession and teacher self-efficacy are inextricably linked for successful teaching and 
learning in technology eras and beyond. The realization of this fact serves as a positive step towards enhancing effective educational service delivery. The actualization of the above expectations depends on teacher self-efficacy.

Self-efficacy affects every area of human endeavor including teaching. Teacher selfefficacy, according to Bandura [14], is a teacher's assessment of his or her ability to plan and carry out the activities required to complete a task following intended outcomes. Graham [15] defined self-efficacy as the belief in one's ability to succeed in specific tasks or situations. It also refers to how an individual behaves, thinks, and motivates to be involved in a given task and to execute the task successfully.

Self-efficacy has many positive effects and benefits especially among teachers whose aspiration tends to have higher self-efficacy and attain higher achievements in teaching Basic Technology. The focus is not on the teachers' skills but on the judgmental part of what the teachers can do with the type of skills they possess or procedures utilized to develop the skill to enhance students' learning outcomes. People who believe they are extremely efficacious behave, think, see, and feel differently from those who believe they are ineffective, according to Graham. Teachers' self-efficacy refers to a teacher's conviction in his or her ability to educate and affect students' conduct and accomplishment independent of outside factors or obstacles [16]. Teachers' selfefficacy is a strong self-regulatory feature that allows them to maximize their abilities to help pupils learn more effectively [17]. Teachers with high self-efficacy often take on more efforts, persist in the face of difficulty, and use strategies to make learning meaningful while teachers with low aspiration tend to have lower self-efficacy beliefs when they encounter obstacles, and give up easily, and are more frustrated in teaching Basic Technology [18]. Many teachers in Basic Technology classes now have poor self-efficacy, which is why many topics were not taught for understanding, and therefore for examination purposes, in both classrooms and workshops. Low teacher selfefficacy may be to blame for the lower level of learning outcomes commonly observed in science and technology [19]. Instructors' views about themselves and their skills, according to Marsh \& Martin [20], can influence the quality of their performance; teachers' self-efficacy varies considerably depending on their credentials, and teachers' self-efficacy is important to good teaching.

Self-efficacy has been demonstrated in studies to have a major impact on how people approach objectives, tasks, and problems in life, including teaching challenges. Redmond [21] posited that teachers' self-efficacy is influenced by past successes and failures which can subsequently impact future successes or failures. An individual's power and determination to function amid odds, challenges, and complications of life depends on his/her self-efficacy. This means that a teacher who believes he or she can perform well in his or her job is more likely to see teaching challenges as tasks to master rather than avoid. Schwarzer \& Hallum [22] added that teachers with high self-efficacy were optimistic in their profession while those with low self-efficacy were pessimistic.

Several reasons have been attributed to students' poor performance in school subjects. Among these are the school curricula, the quantity of well-qualified teachers, poor teacher preparation, dearth of learning materials, teachers' self-efficacy, parents, lack of good facilities [23]. The achievement of national technological progress, as stated in the national education policy, is primarily dependent on teacher certification. Basic Technology aims to raise awareness and build interest in pupils as well as necessary scientific abilities to prepare them for technological applications that will inspire and improve their creativity. This admirable goal will be thwarted if the students are taught by inept (low self-efficacy) teachers. Teachers like these would be unable to effectively and sufficiently convey information to students. 
Public secondary school students in Nigeria have been performing poorly due to unqualified and incompetent teachers. Teacher qualification is one of the predictors of their self-efficacy which contributes positively to their students; learning outcomes. Self-efficacy is among the strong consistent measure of teachers' future success in the classroom ensuring teacher quality in content delivery. Teachers' low content knowledge in school subjects [24], inability to perform experiments and other practical [25], and inability to use technology in presenting instructions [26] have prompted researchers to investigate the effect of teachers' self-efficacy on instructional delivery. Technical teachers' lack of confidence in Basic Technology classes has become a worsening element linked to their lack of certification and shallow knowledge, which has a detrimental influence on students' learning outcomes [27], [28]. So, how might researchers assist technical educators in their endeavors? As a result, in Edo State public junior secondary schools, it is necessary to assess technical instructors' selfefficacy and credentials in connection to students' learning outcomes in Basic Technology.

Several justifications have been made for the self-efficacy belief of teachers. According to Graham [15], more learner participation in teaching and decision making such as goal setting make learning more purposeful thus, leading to greater success. The learner to achieve this is dependent on the teachers' selfefficacy in the classroom. According to studies, many teachers with poor self-efficacy rely on textbook reading when instructing pupils. While instructing, no competent instructor will read his or her textbook to the pupils. Some lines of research have come together to support the idea that teacher self-efficacy has a beneficial impact on student learning outcomes. To this aim, Henson [29] argued that teacher efficacy is reliably linked to positive instructional behavior and student learning outcomes. Teachers' selfefficacy increases motivation on the student and helps the learner to develop the ability to think and act inter-dependently and the learner to play active participatory roles.

Maddux in [30] studied pupil-teacher beliefs about self-efficacy in the British educational context using 112 pupil teachers. 20 volunteer teachers were interviewed in groups to identify their general attitudes towards teachers' self-efficacy. The findings revealed that pupil-teachers belief is positive towards the adoption of the self-efficacy principle. Owie \& Schwarzer in [8] conducted a study on the strategies for promoting Teachers' self-efficacy in the English language in South Africa using 176 teachers and found that the English language curriculum does not promote teachers' self-efficacy. Some of the issues identified were that teachers were not exposed to routine opportunities and were not trained in the use of innovations, thereby hindering their self-efficacy.

Students taught by highly effective instructors have a high degree of academic success, autonomy, motivation, and a solid conviction in their efficacy, according to Tschannem-Moran \& Hoy [19]. The feeling of self-efficacy among teachers has been linked to certain good elements of the job. One of these features, according to Dellinger et al. [31], is that the instructor is more passionate and happy with his or her job. This means that academics should focus on the nature of instructors' perceptions of self-efficacy, among other things, to understand the phenomena of poor success in school topics, including Basic Technology. This study was done in Edo State to evaluate the link between technical teachers' self-efficacy and students' academic success in Basic Technology.

The social cognitive theory propounded by Bandura [32] guided this study. It is a psychological concept that is based on the idea that people are active participants in their growth. Apart from personal and contextual variables, individuals have self-beliefs that allow them to exert some control over their thoughts, feelings, and behaviors, according to social cognition theory. Self-efficacy is fueled 
by four primary sources, according to Bandura:

(1) social persuasion; (2) vicarious experience;

(3); psychological and emotional states, and (4) mastery experiences.

Although mastery experience is generally seen to be the most effective approach to develop a strong sense of self-efficacy, psychological and emotional arousal may also boost self-efficacy when a person can decrease stress reactions and change bad inclinations when confronted with adversity. Mastery experiences are the interpreted consequences of purposeful performance, such as comparing a teacher's prior efficacy to their current efficacy to evaluate if self-efficacy is growing or not. The vicarious experience involves observing others succeed at a task, which may raise the belief that the observer could also succeed in performing the task. The impact of other instructors' actions or a teacher's or person's assessment of performance in relation to the performance of another individual or teachers are examples of vicarious experiences, and whether they conclude it to be a success or failure, or it can be seeing another teacher succeeding at particular handwork which may boost others self-efficacy. When a person is convinced or persuaded that he or she has the skills to succeed at a task, this is known as social persuasion. Social persuasion is about the social messages received from others or encouragements that technical teachers receive from influential sources including teacher educators, other colleagues, friends, peers, parents, and the larger society.

According to Podell \& Soodak [33], teacher efficacy, or the degree to which a teacher feels he or she is capable of influencing students' learning outcomes, has a beneficial impact on teachers' efforts and perseverance in the face of adversity. According to this research, instructors' strong self-efficacy is a characteristic that favorably influences students' learning and learning outcomes.

The objective of this study is to examine the link between technical instructors' selfefficacy and students' Basic Technology learning outcomes in Edo State. The goal of this study was to find out (1) the relationship between technical teachers' qualification and their self-efficacy; (2) the relationship between technical teachers' self-efficacy and students' learning outcome in Basic Technology; and (3) the relationship between technical teachers' self-efficacy and qualifications on students' learning outcomes in Basic Technology.

\section{METHOD}

A correlation research design was adopted in this study. The correlation research design helps to determine the degree of relationship that exists between two or more variables. This design was adopted in this study because the researchers studied the relationships that existed between technical teachers' selfefficacy and students' learning outcomes in Basic Technology in Edo State.

The study's population comprised of all the 178 technical teachers and 15,886 JSS III students that offered Basic Technology in public junior secondary schools as of the 2017/2018 academic session in Edo State. A multi-stage sampling technique was adopted in the selection of schools for this study. Six local governments were selected as clusters and the schools were selected using a simple random sampling technique within the clusters. A purposive random sampling technique was used to sample 126 technical teachers involved in this study.

The data collection instrument utilized was Teacher Self-efficacy scale (TSES). TSES was adopted from Tschanne-Moran \& Woolfolk [19] with a Cronbach Alpha reliability coefficient of .76. The students' JSS III mock examination scores from the sampled schools were used for their academic performance.

The researchers with the help of three research assistants administered the questionnaire. The instruments were collected immediately before leaving each school. The reason was to ensure a high return rate of the instrument. Also, the mock results of the 
students taught by each Basic Technology teacher were collected together with the questionnaire from each of the teachers. The exercise lasted five weeks.

Pearson Product Moment Correlation Coefficient and regression analysis were used to examine the data gathered. Decision rules for retaining or rejection were if probability value was more than the Alpha value it is retained but if the Alpha value is more probability value, it was rejected.

\section{RESULTS AND DISCUSSION}

Table 1 shows the relationship between technical teachers' qualifications and students' learning outcomes in Basic Technology. It reveals that the correlation between technical teachers' qualifications and students' learning outcomes in Basic Technology was .63. This means that there was a substantial link between instructors' qualifications and pupils' fundamental technology learning results. .63 is related with a coefficient of determination of .40. The coefficient of determination of .40 , also known as the predictive value, implies that $40 \%$ of the difference in students' academic achievement in Basic Technology was explained by their instructors' qualifications. This means that $60 \%$ of the variation in students' learning outcomes in Basic Technology is attributed to factors other than technical teachers' qualifications. The first hypothesis is there is no significant relationship between technical teachers' qualifications and students' learning outcomes in Basic Technology.

Table 1. Pearson's Product Moment Correlation Analysis of the Relationship between Technical Teachers' Qualification and Students' Learning Outcomes in Basic Technology

\begin{tabular}{|c|c|c|c|}
\hline \multicolumn{2}{|r|}{ Variable } & \multirow[t]{2}{*}{$\mathrm{X}$} & \multirow[t]{2}{*}{ SD } \\
\hline $\mathrm{N}$ & $\mathrm{R}^{2}$ & & \\
\hline \multirow{3}{*}{126} & Teachers' Qualification & 60.59 & 9.13 \\
\hline & .40 & & \\
\hline & Teachers' self-efficacy & 51.67 & 8.45 \\
\hline
\end{tabular}

Table 2 indicates the regression analysis findings, which reveal an F-value of 81.24 and an associated exact probability value of .00 . It was found that there was a significant link between technical instructors' qualifications and students' learning outcomes in Basic Technology since the precise $p$-value of .00 was less than the .05 chosen as the bench standard. As a result, the null hypothesis that there is no significant link between technical instructors' qualifications and students' fundamental technology learning results was rejected.

Table 2. Regression Analysis of Teachers' Qualification and Their Self-Efficacy

\begin{tabular}{|c|c|c|c|}
\hline \multicolumn{2}{|c|}{ Model } & \multirow{2}{*}{$\begin{array}{l}\text { Sum of Squares } \\
\text { Sig. }\end{array}$} & \multirow[t]{2}{*}{$\mathrm{df}$} \\
\hline Mean Square & $\mathrm{F}$ & & \\
\hline \multicolumn{2}{|c|}{ Regression } & 4125.418 & 1 \\
\hline 4125.418 & 81.236 & .000 & \\
\hline \multicolumn{2}{|c|}{ Residual } & 6297.122 & 124 \\
\hline \multicolumn{4}{|l|}{50.783} \\
\hline \multicolumn{2}{|l|}{ Total } & 10422.540 & 125 \\
\hline
\end{tabular}

Table 3 demonstrates the relationship between technical teachers' self-efficacy and students' learning outcomes in Basic Technology.

Table 3. Pearson's Product Moment Correlation Analysis of the Relationship between Technical Teachers' Self-Efficacy and Students' Learning Outcomes in Basic Technology

\begin{tabular}{|c|c|c|c|c|}
\hline \multicolumn{3}{|c|}{ Variable } & \multirow[t]{2}{*}{$\mathrm{X}$} & \multirow[t]{2}{*}{ SD } \\
\hline $\mathrm{N}$ & $\mathrm{r}$ & $\mathrm{R}^{2}$ & & \\
\hline \multicolumn{3}{|c|}{ Teachers' self-efficacy } & 60.59 & 9.13 \\
\hline 126 & .45 & .21 & & \\
\hline \multicolumn{3}{|c|}{ Students' learning outcomes } & 63.32 & 5.94 \\
\hline
\end{tabular}

The result in Table 3 reveals that the relationship between technical teachers' selfefficacy and students' learning outcome in Basic Technology was .45. This suggests a moderate favorable relationship between technical teachers' self-efficacy and students' Basic Technology learning outcomes. .45 is related with a coefficient of determination of .21. The coefficient of determination .21, also 
known as the predictive value, indicates that the self-efficacy of technical teachers accounted for $21 \%$ of the variation in students' Basic Technology learning outcomes. This indicates that factors other than technical instructors' selfefficacy account for $79 \%$ of the variation in students' learning results in Basic Technology. The second hypothesis is there is no significant relationship between technical teachers' selfefficacy and students' learning outcomes in Basic Technology.

Table 4 reveals that an F-value of 31.51 with an associated exact p-value of .00 was obtained. Since the exact p-value of .00 was less than the .05 level of significance set as the benchmark, it was concluded that there was a significant relationship between technical teachers' self-efficacy and students' learning outcomes in Basic Technology. Therefore, the null hypothesis which states that there is no significant relationship between technical teachers' self-efficacy and students' learning outcomes in Basic Technology was rejected.

Table 4. Regression Analysis of Technical Teachers' SelfEfficacy and Students' Learning Outcomes in Basic Technology

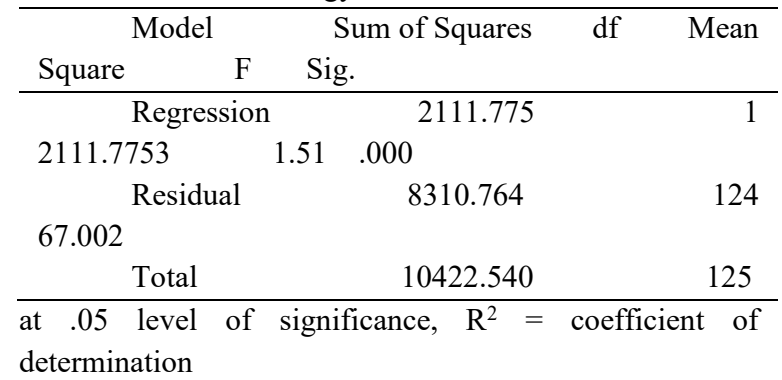

The inter-correlation between technical teachers' self-efficacy and qualification on students' learning outcomes in Basic Technology is described in Table 5.

Table 5. A Model Summary of the Inter-Correlation between Technical Teachers' Self-Efficacy and Qualification on Students' Learning Outcomes in Basic Technology

\begin{tabular}{lll}
\hline $\begin{array}{c}\text { Model } \\
\text { Adjusted } \mathrm{R}^{2}\end{array}$ & $\mathrm{r}$ & $\mathrm{R}^{2}$ \\
\hline 1 & .65 & .42 \\
.41 & & \\
\hline $\begin{array}{l}\mathrm{R}^{2}=\text { coefficient of determination, } \\
\text { and qualification }\end{array}$ & & \\
\end{tabular}

The coefficient of determination $\mathrm{R} 2$ was .42 , and the correlation between the predictor variables (self-efficacy and qualification) and the criterion variable (students' academic achievement in Basic Technology) was .65. This implies that the model as a whole explained $42 \%$ of the total variance of selfefficacy and qualification that is accountable for students' learning outcomes in Basic Technology. The third hypothesis is there is no significant inter-correlation between technical teachers' self-efficacy and qualification on students' learning outcomes in Basic Technology in Edo State.

Table 6 shows that an F-value of 44.92 was achieved, with a corresponding exact probability value of .00 . This precise probability value of .00 was judged to be significant even though it was less than the.05 level of significance. As a result, the null hypothesis was rejected, claiming that there is no significant inter-correlation between technical teachers' self-efficacy and qualification and students' learning results in Basic Technology in Edo State. The conclusion was that in Edo State, there is a strong intercorrelation between self-efficacy, qualification, and students' learning results in Basic Technology.

Table 6. Regression Analysis of Technical Teachers' SelfEfficacy and Students' Learning Outcomes in Basic Technology

\begin{tabular}{|c|c|c|c|}
\hline \multicolumn{2}{|c|}{ Model } & \multirow{2}{*}{$\begin{array}{l}\text { Sum of Squares } \\
\text { Sig. }\end{array}$} & \multirow[t]{2}{*}{$\mathrm{df}$} \\
\hline Mean Squar & $\mathrm{F}$ & & \\
\hline \multicolumn{2}{|c|}{ Regression } & 4399.369 & 2 \\
\hline 199.685 & 44.920 & .000 & \\
\hline \multirow{2}{*}{\multicolumn{2}{|c|}{48.969 Residual }} & 6023.171 & 123 \\
\hline & & & \\
\hline \multicolumn{2}{|c|}{ Total } & 10422.540 & 125 \\
\hline
\end{tabular}

In Edo State, the results of this study indicated a substantial positive link between technical instructors' qualifications and their self-efficacy. This study supports Jackson \& Davis [34] that teacher training increased teaching abilities and knowledge, therefore improving content delivery and learning 
outcomes. Also, Gopal \& Stears [35] and Omolara [36] revealed that professional qualification impacts instructors' skills, which is consistent with the findings of this study. Uzodinma \& Onwurah [37] found no link between self-efficacy and teacher certification status in science, which contradicts the findings of this study. The findings of this study contrast those of Feng \& Sass [38], who found no statistically significant link between instructors' educational level and pupils' academic achievement. According to Dahar et al. [39], there was no significant difference in teacher quality between schools with better academic success and those with lower academic achievement, which contradicts the findings of this study. According to a study done by Kimani et al. [40], more professional credentials beyond a bachelor's degree do not always contribute to better teaching competency at the secondary school level. Similarly, Musau \& Migosi [41] found that teacher qualification had no substantial impact on students' academic achievement, which contradicts this study's findings.

The data also show there was a moderate positive relationship between teachers' selfefficacy and students' learning outcomes in Basic Technology in Edo State. Table 2 and Table 4 indicate a moderate favorable connection between instructors' self-efficacy and students' learning outcomes in Basic Technology in Edo State. This conclusion is consistent with that of Yoe et al. [42], who discovered a favorable link between instructors' instructional self-efficacy and student accomplishment. Tanya [43] found that collective teacher efficacy influenced students' success, which is consistent with the findings of this study. The findings of this study are consistent with the findings of Schwarzer \& Gerdamarie [44], who found that strong teacher self-efficacy correlates to higher performance in the teaching and learning process. AlvarezNunez [45] revealed that instructors' selfefficacy beliefs had a substantial impact on students' grades, which is consistent with the findings of this study. Similarly, Kim \& Seo [46] in their study found that the mean relationship between teacher efficacy and students' academic achievement was significant supports the finding of this study.

Furthermore, the findings reveal that $79 \%$ of the variation in students' learning outcomes in Basic Technology is attributed to factors other than technical teachers' self-efficacy. This is consistent with the findings of Kimani et al. [40], who found that teacher job group, teaching workload, administration, marking and revision of students' assignments, and provision of individualized attention to weak students all contribute significantly to students' academic performance in secondary schools, but not teacher qualification or self-efficacy.

\section{CONCLUSION}

According to the findings of this study, technical teachers should strive for high efficacy to improve students' academic achievement in Basic Technology. Technical teachers should not allow their educational level to dissuade students from studying Basic Technology, and they should also teach students about the importance of Basic Technology in the educational system and society at large. The following suggestions were made based on the findings of this study. Technical teachers should be more committed and optimistic about the profession to improve their self-efficacy so that they can prepare their students with what is expected of them. Stakeholders should endeavor to give technical teachers more opportunities that will boost their self-efficacy. Technical teachers' self-efficacy should be given much consideration as it relates to students' academic performance.

\section{REFERENCES}

[1] R. Uwameiye and J. Oviawe, "Professional competency needs of introductory technology teachers in southern Nigeria," Indian J. Vocat. 
Educ., vol. 8, no. 1, pp. 1-11, 2006.

[2] D. R. Ejima and S. Okutachi, "Teacher professional development in the $21 \mathrm{st}$ century Nigeria: The journey, the potholes and the patches," Glob. Voice Educ., vol. 1, no. 1, pp. 122-125, 2012.

[3] T. Owolabi, "Characteristics of professional development and impact of training on science teachers' classroom practice," Univers. J. Educ. Gen. Stud., vol. 1, no. 5, pp. 119-125, 2012.

[4] J. I. Oviawe, "Professional teaching competencies required by lecturers for effective implementation of technical drawing curriculum in tertiary institutions in South-South Nigeria," $J$. Educ. Realities, vol. 8, no. 1, pp. 12-29, 2019.

[5] J. I. Oviawe, "Effect of studentinteraction patterns on students' academic performance in Basic Technology in Edo State secondary schools," J. Technol. Oper. Manag., vol. 15, no. 1, pp. 1-14, Jul. 2020, doi: 10.32890/jtom2020.15.1.1.

[6] Nigerian Federal Ministry of Education, Junior Secondary School Curriculum Basic Technology for JSS 1-3. Abuja: Nigerian Educational Research and Development Council, 2010.

[7] M. J. Akomolafe, A. O. Ogunmakin, and G. M. Fasooto, "The role of academic self-efficacy, academic motivation and academic self-concept in predicting secondary school students' academic performance," J. Educ. Soc. Res., vol. 3, no. 2, 2013, doi: 10.5901/JESR.2013.V3N2P335.

[8] F. Sepehrian Azar, "Self-efficacy, achievement motivation and academic procrastination as predictors of academic achievement in pre-college students," Educ. J. Teach. Educ., vol. 3, no. 11, pp. 847-857, 2013.

[9] A. A. Nwosu, "Instructional analogies as an effective alternative strategy in science classrooms."
[10] M. Udofot, "Teacher education, innovation and the challenges of implementation in Nigeria," J. Child. Second. Educ., vol. 7, no. 1, 2010.

[11] C. R. Aguba, "Achieving national greatness through education that matters: Search light on teacher education," 2015.

[12] B. Mary, N. Ann, and C. J. Koskey, "The influence of examination on the stated curriculum goals," Am. Int. J. Contemp. Res., vol. 2, no. 2, pp. 179182, 2012.

[13] College Foundation of North Carolina (CFNC), Teaching Profession. College Foundation of North Carolina, 2014.

[14] A. Bandura, Social Foundation of Thought and Action: A Social Cognitive Theory. New Jersey: Prentice-Hall, 1986.

[15] S. Graham, "Self-efficacy and academic listening," J. English Acad. Purp., vol. 10, no. 2, pp. 113-117, Jun. 2011, doi: 10.1016/J.JEAP.2011.04.001.

[16] P. Gavora, "Measuring the self-efficacy of in-service teachers in Slovakia," Orb. Sch., vol. 5, no. 2, pp. 79-94, Feb. 2018, doi: 10.14712/23363177.2018.102.

[17] A. A. Adediwura and B. Tayo, "Perception of teachers' knowledge, attitude and teaching skills as predictor of academic performance in Nigerian secondary schools," Educ. Res. Rev., vol. 2, no. 7, pp. 165-171, 2007.

[18] C. Kendra, Social Learning Theory. 2015.

[19] M. Tschannen-Moran and A. W. Hoy, "Teacher efficacy: Capturing an elusive construct," Teach. Teach. Educ., vol. 17, no. 7, pp. 783-805, Oct. 2001, doi: 10.1016/S0742-051X(01)00036-1.

[20] H. W. Marsh and A. J. Martin, "Academic self-concept and academic achievement: Relations and causal ordering," Br. J. Educ. Psychol., vol. 81, no. 1, pp. 59-77, Mar. 2011, doi: 10.1348/000709910X503501. 
[21] B. F. Redmond, Self-Efficacy and Social Cognitive Theories. 2010.

[22] R. Schwarzer and S. Hallum, "Perceived teacher self-efficacy as a predictor of job stress and burnout: Mediation analyses," Appl. Psychol., vol. 57, no. SUPPL. 1, pp. 152-171, Jul. 2008, doi: 10.1111/J.1464-0597.2008.00359.X.

[23] O. Ahiakwo, Science, Science Education and Scientific Literacy. 2003.

[24] S. C. Wu and Y. L. Chang, "Elementary teacher education and teacher efficacy toward mathematics and science," in Proceedings of the 30th conference of the international group for the psychology of mathematics education, 2006, vol. 5, pp. 417-424.

[25] J. W. F. Muwanga-Zake, "Is science education in a crisis? Some of the problem in South Africa," African J. Res. Math. Sci. Technol. Educ., vol. 4, no. 1, pp. 1-11, 2000, doi: 10.1080/10288457.2000.10756114.

[26] M. Hakverdi, B. Gucum, and H. Korkmaz, "Factors influencing preservice science teachers' perception of computer self-efficacy," Asia Pacific Forum Sci. Learn. Teach., vol. 8, no. 1, pp. 1-14, 2007.

[27] G. Onwu and N. Stoffels, "Instructional functions in large, under-resourced science classes: Perspectives of South African teachers," Perspect. Educ., vol. 23, no. 3, pp. 79-91, 2005.

[28] F. Arends and M. Phurutsi, Teacher Education in South Africa Series: Beginner Teachers in South Africa: School Readiness, Knowledge and Skills. HSRC, 2009.

[29] R. K. Henson, "Relationships between preservice teachers' self-efficacy, task analysis, and classroom management beliefs," Research in the Schools, vol. 10, no. 1. pp. 53-62, Feb. 03, 2003.

[30] A. S. Mohammed and A. Z. Abubakar, "Relationship between senior secondary school science teachers' self-efficacy and their students' achievement," Int. J. Trop. Educ. issues, vol. 3, no. 2, pp. 191-199, 2019.

[31] A. B. Dellinger, J. J. Bobbett, D. F. Olivier, and C. D. Ellett, "Measuring teachers' self - efficacy beliefs: Development and use of the TEBSSelf," Teach. Teach. Educ., vol. 24, no. 3, pp. 751-766, Apr. 2008, doi: 10.1016/J.TATE.2007.02.010.

[32] A. Bandura, Self-Efficacy: The Exercise of Control. Cambridge: Cambridge University Press., 1997.

[33] D. M. Podell and L. C. Soodak, "Teacher efficacy and bias in special education referrals," J. Educ. Res., vol. 86, no. 4, pp. 247-253, 1993, Accessed: Oct. 15, 2021. [Online]. Available: https://www.jstor.org/stable/27541871.

[34] A. W. Jackson and G. A. Davis, Turning Points 2000: Educating Adolescents in the 21st Century. New York: Teacher's College press, 2000.

[35] N. Gopal and M. Stears, "An alternative approach to assessing science competencies," African J. Res. Math. Sci. Technol. Educ., vol. 11, no. 2, pp. 15-23, 2007, doi: 10.1080/10288457.2007.10740618.

[36] B. E. Omolara, "Pedagogical Approaches to the Teaching and Learning of School Subjects in Africa in the 21st Century," 2008.

[37] E. U. Uzodinma and C. N. Onwurah, "Perceived self-efficacy belief of primary school teachers in Enugu State," Int. J. Educ. Res., vol. 14, no. 4, pp. 6673, 2015.

[38] L. Feng and T. R. Sass, "Teacher quality and teacher mobility," Educ. Financ. Policy, vol. 12, no. 3, pp. 396-418, Jul. 2017, doi: 10.1162/EDFP_A_00214.

[39] M. . Dahar, R. A. Dahar, R. T. Dahar, and F. A. Faize, "Impact of teacher quality on the academic achievement of students at secondary stage in Punjab (Pakistan)," Eur. J. Soc. Sci., vol. 19, no. 
1, pp. 97-105, 2011.

[40] G. Kimani, A. Kara, and L. Njagi, "Teacher factors influencing students' academic achievement in secondary schools in Nyandarua county, Kenya," Int. J. Educ. Res., vol. 1, no. 3, pp. 114, 2013.

[41] L. M. Musau and M. J. Abere, "Teacher qualification and students' academic performance in science, mathematics and technology subjects in Kenya," Int. J. Educ. Adm. Policy Stud., vol. 7, no. 3, pp. 83-89, May 2015, Accessed: Oct. 15, 2021. [Online]. Available: http://www.academicjournals.org/IJEAP S.

[42] L. S. Yeo, R. P. Ang, W. H. Chong, V. S. Huan, and C. L. Quek, "Teacher efficacy in the context of teaching low achieving students," Curr. Psychol., vol. 27 , no. 3, pp. 192-204, Sep. 2008, doi: 10.1007/S12144-008-9034-X.
[43] E. Tanya, "Collective Teacher Efficacy and Students Achievement," Western Illiniois University, 2009.

[44] G. S. Schmitz and R. Schwarzer, "Perceived self-efficacy and teacher burnout: A longitudinal study in ten schools," J. Educ. Psychol., vol. 14, no. 1, pp. 12-25, Sep. 2006, doi: 10.1024//1010-0652.14.1.12.

[45] T. M. Alvarez-Nunez, "Teacher selfefficacy: A link to student achievement in English language and mathematics in Belizean primary schools," Oklahoma State University, 2012.

[46] K. R. Kim and E. H. Seo, "The relationship between teacher efficacy and students' academic achievement: A meta-analysis," Soc. Behav. Pers., vol. 46, no. 4, pp. 529-540, 2017, doi: 10.2224/SBP.6554. 